\title{
A novel thermostable $\mathrm{GH} 10$ xylanase
} with activities on a wide variety of cellulosic substrates from a xylanolytic Bacillus strain exhibiting significant synergy with commercial Celluclast $1.5 \mathrm{~L}$ in pretreated corn stover hydrolysis

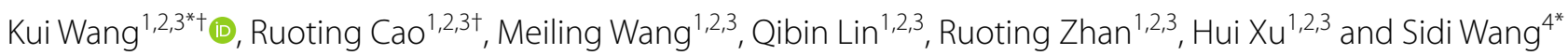

\begin{abstract}
Background: Cellulose and hemicellulose are the two largest components in lignocellulosic biomass. Enzymes with activities towards cellulose and xylan have attracted great interest in the bioconversion of lignocellulosic biomass, since they have potential in improving the hydrolytic performance and reducing the enzyme costs. Exploring glycoside hydrolases (GHs) with good thermostability and activities on xylan and cellulose would be beneficial to the industrial production of biofuels and bio-based chemicals.

Results: A novel GH10 enzyme (XynA) identified from a xylanolytic strain Bacillus sp. KW1 was cloned and expressed. Its optimal pH and temperature were determined to be $\mathrm{pH} 6.0$ and $65^{\circ} \mathrm{C}$. Stability analyses revealed that XynA was stable over a broad $\mathrm{pH}$ range $(\mathrm{pH} 6.0-11.0)$ after being incubated at $25^{\circ} \mathrm{C}$ for $24 \mathrm{~h}$. Moreover, $\mathrm{XynA}$ retained over $95 \%$ activity after heat treatment at $60^{\circ} \mathrm{C}$ for $60 \mathrm{~h}$, and its half-lives at $65^{\circ} \mathrm{C}$ and $70^{\circ} \mathrm{C}$ were about $12 \mathrm{~h}$ and $1.5 \mathrm{~h}$, respectively. More importantly, in terms of substrate specificity, XynA exhibits hydrolytic activities towards xylans, microcrystalline cellulose (filter paper and Avicel), carboxymethyl cellulose (CMC), cellobiose, $p$-nitrophenyl- $\beta$-D-cellobioside $(p N P C)$, and $p$-nitrophenyl- $\beta$-D-glucopyranoside ( $p N P G)$. Furthermore, the addition of XynA into commercial cellulase in the hydrolysis of pretreated corn stover resulted in remarkable increases (the relative increases may up to 90\%) in the release of reducing sugars. Finally, it is worth mentioning that XynA only shows high amino acid sequence identity (88\%) with rXynAHJ14, a GH10 xylanase with no activity on CMC. The similarities with other characterized GH10 enzymes, including xylanases and bifunctional xylanase/cellulase enzymes, are no more than $30 \%$.
\end{abstract}

Conclusions: XynA is a novel thermostable GH10 xylanase with a wide substrate spectrum. It displays good stability in a broad range of $\mathrm{pH}$ and high temperatures, and exhibits activities towards xylans and a wide variety of cellulosic

\footnotetext{
*Correspondence: uk0829@126.com; wangsd@gzucm.edu.cn

${ }^{\dagger}$ Kui Wang and Ruoting Cao contributed equally to this work

${ }^{1}$ Research Center of Chinese Herbal Resource Science and Engineering,

Guangzhou University of Chinese Medicine, Guangzhou Higher

Education Mega Center, No.232 Outer Ring West Rd., Panyu District,

Guangzhou 510006, Guangdong, China

${ }^{4}$ College of Fundamental Medical Science, Guangzhou University

of Chinese Medicine, Guangzhou Higher Education Mega Center, No.232

Outer Ring West Rd., Panyu District, Guangzhou 510006, Guangdong,

China

Full list of author information is available at the end of the article
}

(c) The Author(s) 2019. This article is distributed under the terms of the Creative Commons Attribution 4.0 International License (http://creativecommons.org/licenses/by/4.0/), which permits unrestricted use, distribution, and reproduction in any medium, provided you give appropriate credit to the original author(s) and the source, provide a link to the Creative Commons license, and indicate if changes were made. The Creative Commons Public Domain Dedication waiver (http://creativecommons.org/ publicdomain/zero/1.0/) applies to the data made available in this article, unless otherwise stated. 
substrates, which are not found in other GH10 enzymes. The enzyme also has high capacity in saccharification of pretreated corn stover. These characteristics make XynA a good candidate not only for assisting cellulase in lignocellulosic biomass hydrolysis, but also for the research on structure-function relationship of bifunctional xylanase/cellulase.

Keywords: Bacillus, GH10 enzyme, Bifunctional xylanase/cellulase, Thermostable, Synergy, Promiscuity, Lignocellulose

\section{Background}

Lignocellulosic biomass is abundant in nature and represents a promising and renewable resource for the production of biofuels and bio-based chemicals [1]. Cellulose and hemicellulose are the first and second largest components of lignocellulosic biomass, with a ratio of $40.6-51.2 \%$ and $28.5-37.2 \%$, respectively [2]. Furthermore, xylan is one of the main constituents of hemicellulose. Due to the structural complexity of lignocellulosic biomass, its efficient enzymatic deconstruction requires the synergistic action of a group of biocatalysts including cellulase and endoxylanase [3-5], and thus leading to the relatively high use-cost of enzymes. Thermostable enzymes have advantages over their mesophilic counterparts since the various industrial processes need to go through high-temperature processes [6]. Therefore, thermostable glycoside hydrolases (GHs) with cellulase and xylanase activities would be more favorable in the degradation of lignocellulosic biomass for their potential for improving the hydrolytic performance, cost saving, and wide scope of application.

In the Carbohydrate-Active EnZymes (CAZy) Database, the overwhelming majority of enzymes classified into GH family 10 (GH10) are xylanase without reported cellulase activity [7]. However, a few xylanases with only a GH10 catalytic domain were reported to exhibit promiscuous activities towards different cellulose substrates besides xylans. For example, GH10 catalytic domains derived from Cellulomonas fimi [8], Ampullaria crossean [9], and Bacillus stearothermophilus [10, 11] show activities towards substrates such as $p \mathrm{NPC}, \mathrm{CMC}$, and $p$ NPG. A Demequina sp. xylanase (Mxyn10) containing a GH10 catalytic domain linked with a carbohydratebinding module (CBM) exhibits activities against CMC and barley glucan [12]. The GH10 module of CbXyn10C/Cel48B from Caldicellulosiruptor bescii, CbXyn10C, is able to degrade microcrystalline cellulose (filter paper and Avicel) [13]. These studies suggest that GH10 enzymes may be potential candidates for the screening of novel enzymes with activities on xylans and cellulosic substrates.

In this study, a novel GH10 enzyme-coding gene (designated $x y n A$ ) was identified and cloned from a xylanolytic Bacillus strain previously isolated by our group, protein expression was subsequently performed. The enzyme properties and its application in pretreated corn stover hydrolysis were investigated.

\section{Results and discussion}

Identification of a GH10 enzyme from a xylanolytic Bacillus strain

A xylanolytic bacterium Bacillus sp. KW1 was previously isolated and the draft genome was sequenced (unpublished data). A novel gene ( $x y n A)$ encoding a putative GH10 xylanase was identified from the draft genome data. The full-length $x y n A$ encodes a 408 -amino acid residue polypeptide (XynA), only a GH10 catalytic module is detected in XynA (Fig. 1a). The absence of signal peptide suggests that XynA is intracellularly located in Bacillus sp. KW1. In comparison with GH10 xylanases previously characterized, XynA showed highest homology (88\% identity) with the xylanase rXynAHJ14 from Bacillus sp. HJ14 [14] but less than 20\% identity with GH10 xylanases from other Bacillus strains (Table 1) [15-23] and xylanolytic microorganisms [24-27]. Furthermore, a homology search of the Protein Data Bank (PDB) found that XynA shares highest sequence similarity ( $18 \%$ identity) with the GH10 catalytic domain of the Streptomyces zividans xylanase A ( $\mathrm{Xln}_{32 \mathrm{kDa}}$, PDB entry number: $\left.1 \mathrm{XAS}\right)$. Multiple-amino acid sequence alignment was performed, and Glu-182 and Glu-280, mapping to Glu-128 and Glu-236 of $\mathrm{X} \ln \mathrm{A}_{32 \mathrm{kDa}}$, were identified as the putative catalytic amino acids, respectively [28] (Fig. 2). The calculated molecular weight of XynA and its N-terminal fusion tag were about 47.7 and $2.1 \mathrm{kDa}$, respectively; so the total molecular mass of recombinant XynA was about $49.8 \mathrm{kDa}$. Sodium dodecyl sulfate-polyacrylamide gel electrophoresis (SDS-PAGE) analysis of purified XynA found a single band which was a little higher than $45 \mathrm{kDa}$ and was consistent with the calculated mass of recombinant XynA (Fig. 1b).

\section{Influence of $\mathrm{pH}$ and temperature on the activity and stability of XynA}

The optimal reaction $\mathrm{pH}$ for XynA activity is 6.5, and over $60 \%$ of the maximal activities were kept between pH 5.0 and 7.5 (Fig. 3a). As shown in Table 1, GH10 xylanases with different $\mathrm{pH}$ optima have been characterized from Bacillus strains. Besides XynA, recombinant xylanases from Bacillus sp. HJ14, Bacillus sp. HJ2, 


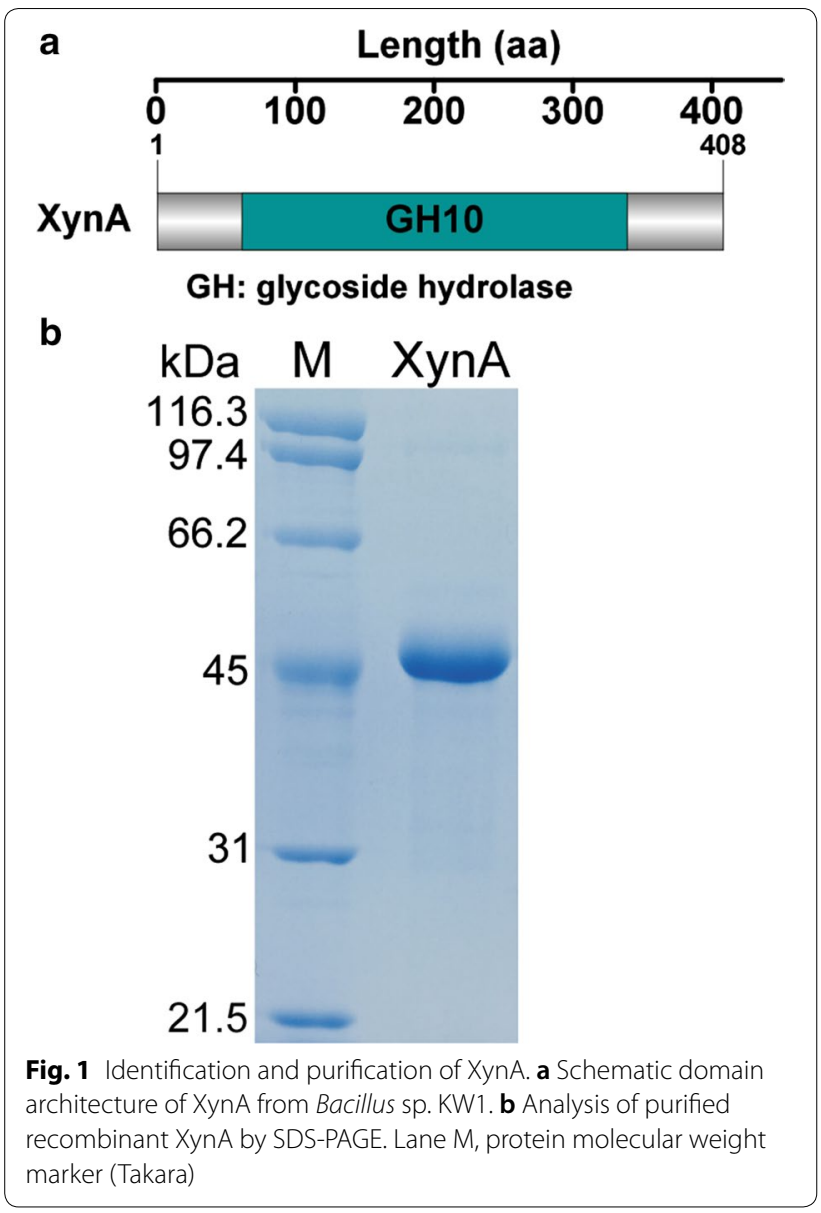

and Bacillus sp. TAR-1 were found to be weak acidic xylanases as well $[14,16,18]$. XynA exhibited the highest activity at $65{ }^{\circ} \mathrm{C}$, and maintained over $65 \%$ of its highest activity in the temperature range of $45-80{ }^{\circ} \mathrm{C}$, and even showed $35 \%$ activity at $85{ }^{\circ} \mathrm{C}$ (Fig. 3b). Similarly, many xylanases from other Bacillus strains also exhibited optimum temperatures around 62.5$70{ }^{\circ} \mathrm{C}[14,20-23]$. The xylanase from $B$. halodurans TSEV1 even had a temperature optimum at $80^{\circ} \mathrm{C}[17]$ (Table 1). Interestingly, although XynA exhibited a $\mathrm{pH}$ optimum of 6.0, the enzyme was more stable at alkaline $\mathrm{pH}$ than at acidic range. When incubated at the $\mathrm{pH}$ range of $6.0-11.0$ for $12 \mathrm{~h}$ at $25^{\circ} \mathrm{C}$, more than $80 \%$ of the activity was retained (Fig. 3c). Similar results were found where xylanases from $B$. halodurans TSEV1 [17] and B. halodurans S7 [22] were stable in wide $\mathrm{pH}$ ranges, including neutral and alkaline conditions. Thermostability analyses showed that XynA was very stable when incubated at 60 and $65{ }^{\circ} \mathrm{C}$, retained $100 \%$ and about $85 \%$ activities after 6 h of incubation, respectively (Fig. 3d). Furthermore, over $95 \%$ and approximately $50 \%$ activity was retained when the incubation time was elongated to $60 \mathrm{~h}$ at $60^{\circ} \mathrm{C}$ and $12 \mathrm{~h}$ at $65{ }^{\circ} \mathrm{C}$, respectively. When incubated at $70{ }^{\circ} \mathrm{C}$, the enzyme gradually lost its activity, with residual activities of about $80 \%$, $71 \%$, and $51 \%$ after $0.5,1$, and $1.5 \mathrm{~h}$ incubation, respectively. However, the half-life of the enzyme at $75{ }^{\circ} \mathrm{C}$ was about $5 \mathrm{~min}$ and almost lost all its activity when incubated for $30 \mathrm{~min}$ (Fig. 3d). As shown in Table 1, the thermostability of XynA is comparable with that of its closest homolog rXynAHJ14, which had a half-life at

Table 1 Comparison of Xyn10A with its homologous Bacillus GH10 xylanases

\begin{tabular}{|c|c|c|c|c|c|c|c|c|}
\hline $\begin{array}{l}\text { Xylanase } \\
\text { (accession no.) }\end{array}$ & Source & Length (aa) & Identity $^{a}$ & $\begin{array}{l}\text { Optimal pH } \\
\text { and Temp. }\end{array}$ & $\begin{array}{l}\text { Stability (temp., } \\
\text { Half-life) }\end{array}$ & $\begin{array}{l}\text { Xylanase } \\
\text { activity }\end{array}$ & $\begin{array}{l}\text { Cellulase } \\
\text { activity }^{b}\end{array}$ & References \\
\hline Xyn10A (MK064556) & Bacillus sp. KW1 & 408 & - & $6.0,65^{\circ} \mathrm{C}$ & $\begin{array}{l}75^{\circ} \mathrm{C}, 5 \mathrm{~min} \\
70^{\circ} \mathrm{C}, 1.5 \mathrm{~h} \\
65^{\circ} \mathrm{C}, 12 \mathrm{~h}\end{array}$ & Yes & Yes & This study \\
\hline $\begin{array}{l}\text { rXynAHJ14 } \\
(\mathrm{AHH02587)}\end{array}$ & Bacilus sp. HJ14 & 409 & $88 \%$ & $6.5,62.5^{\circ} \mathrm{C}$ & $\begin{array}{l}75^{\circ} \mathrm{C}, 25 \mathrm{~min} \\
70^{\circ} \mathrm{C},>60 \mathrm{~min}\end{array}$ & Yes & No & {$[14]$} \\
\hline Xyn10A (AGA16736) & Bacillus sp. SN5 & 338 & $19 \%$ & $7.0,40^{\circ} \mathrm{C}$ & $40^{\circ} \mathrm{C}, 30 \mathrm{~min}$ & Yes & No & {$[15]$} \\
\hline XynAHJ2 (AFE82288) & Bacillus sp. HJ2 & 329 & $18 \%$ & $6.5,35^{\circ} \mathrm{C}$ & $45^{\circ} \mathrm{C},<5 \min$ & Yes & No & {$[16]$} \\
\hline $\begin{array}{l}\text { TSEV1xyl } \\
\text { (AGH25543) }\end{array}$ & B. halodurans TSEV1 & 396 & $14 \%$ & $9.0,80^{\circ} \mathrm{C}$ & $80^{\circ} \mathrm{C}, 35 \mathrm{~min}$ & Yes & No & {$[17]$} \\
\hline XynR (AEP83036) & Bacillus sp. TAR-1 & 396 & $14 \%$ & $6.0,75^{\circ} \mathrm{C}$ & $70^{\circ} \mathrm{C},<15 \mathrm{~min}$ & Yes & - & {$[18,19]$} \\
\hline $\begin{array}{l}\text { NG-27 Xyn } \\
\text { (AAB70918) }\end{array}$ & Bacillus sp. NG-27 & 405 & $13 \%$ & $8.4,70^{\circ} \mathrm{C}$ & $75^{\circ} \mathrm{C},<15 \mathrm{~min}$ & Yes & - & {$[20]$} \\
\hline $\begin{array}{l}\text { BfXyn10A } \\
\text { (AAQ83581) }\end{array}$ & B. firmus & 396 & $13 \%$ & $7.5,70^{\circ} \mathrm{C}$ & $72{ }^{\circ} \mathrm{C}, 4 \mathrm{~h}$ & Yes & No & {$[21]$} \\
\hline XynA (AAV98623) & B. halodurans S7 & 396 & $13 \%$ & $9.0-9.5,70^{\circ} \mathrm{C}$ & $65^{\circ} \mathrm{C},<3.5 \mathrm{~h}$ & Yes & No & {$[22]$} \\
\hline Xyn10 (ADI24221) & Bacillus sp. N16-5 & 392 & $13 \%$ & $7.0,70^{\circ} \mathrm{C}$ & $70^{\circ} \mathrm{C},<10 \mathrm{~min}$ & Yes & No & [23] \\
\hline
\end{tabular}

a The values for amino acid sequence identity were obtained using CLUSTAL W (https://www.genome.jp/tools-bin/clustalw)

b -: the information is not available in the reference 


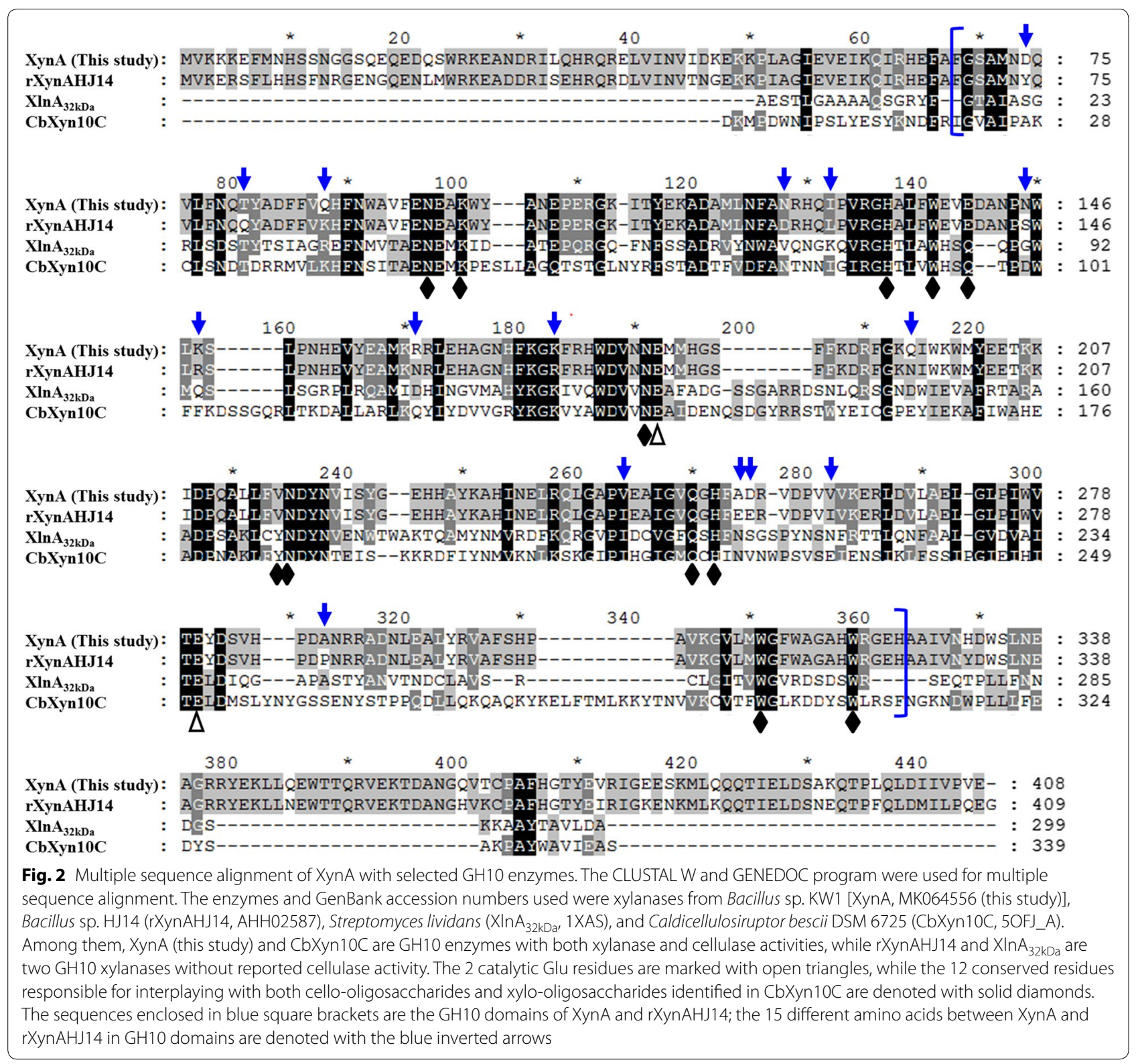

$70{ }^{\circ} \mathrm{C}$ for more than $60 \mathrm{~min}$ [14]. Moreover, the thermostability of XynA is superior to that of many Bacillus GH10 xylanases listed in Table 1, which have shorter half-lives when incubated at high temperatures [15, $16,19,22,23]$, but GH10 xylanases from $B$. halodurans TSEV1 [17] and B. firmus [21] displayed better thermostability; the former's half-life at $80{ }^{\circ} \mathrm{C}$ was $35 \mathrm{~min}$, while the latter displayed a half-life of $4 \mathrm{~h}$ at $72{ }^{\circ} \mathrm{C}$. These results suggested that XynA would be a potential candidate for application in various biotechnological processes that are carried out at high temperatures and in weak acidic-neutral-alkaline $\mathrm{pH}$, such as bioenergy production and paper pulp modification.

\section{Effect of different chemicals on the activity of XynA}

The effects of metal ions, EDTA, urea and Triton X-100 on the xylanase activity of XynA are shown in Table 2. It was noticed that $\mathrm{Ca}^{2+}, \mathrm{Mg}^{2+}, \mathrm{Co}^{2+}$, and $\mathrm{Mn}^{2+}$ activated the enzyme activity at both $1 \mathrm{mM}$ and $10 \mathrm{mM}$ concentrations by $110.8-160 \%$, while $\mathrm{Fe}^{3+}, \mathrm{Fe}^{2+}, \mathrm{Ni}^{2+}$, and EDTA inhibited the enzyme activity by $52.4-91.9 \%$. In the case of $\mathrm{Al}^{3+}$, the enzymatic activity was slightly stimulated at a low concentration $(1 \mathrm{mM})$ and strongly inhibited 

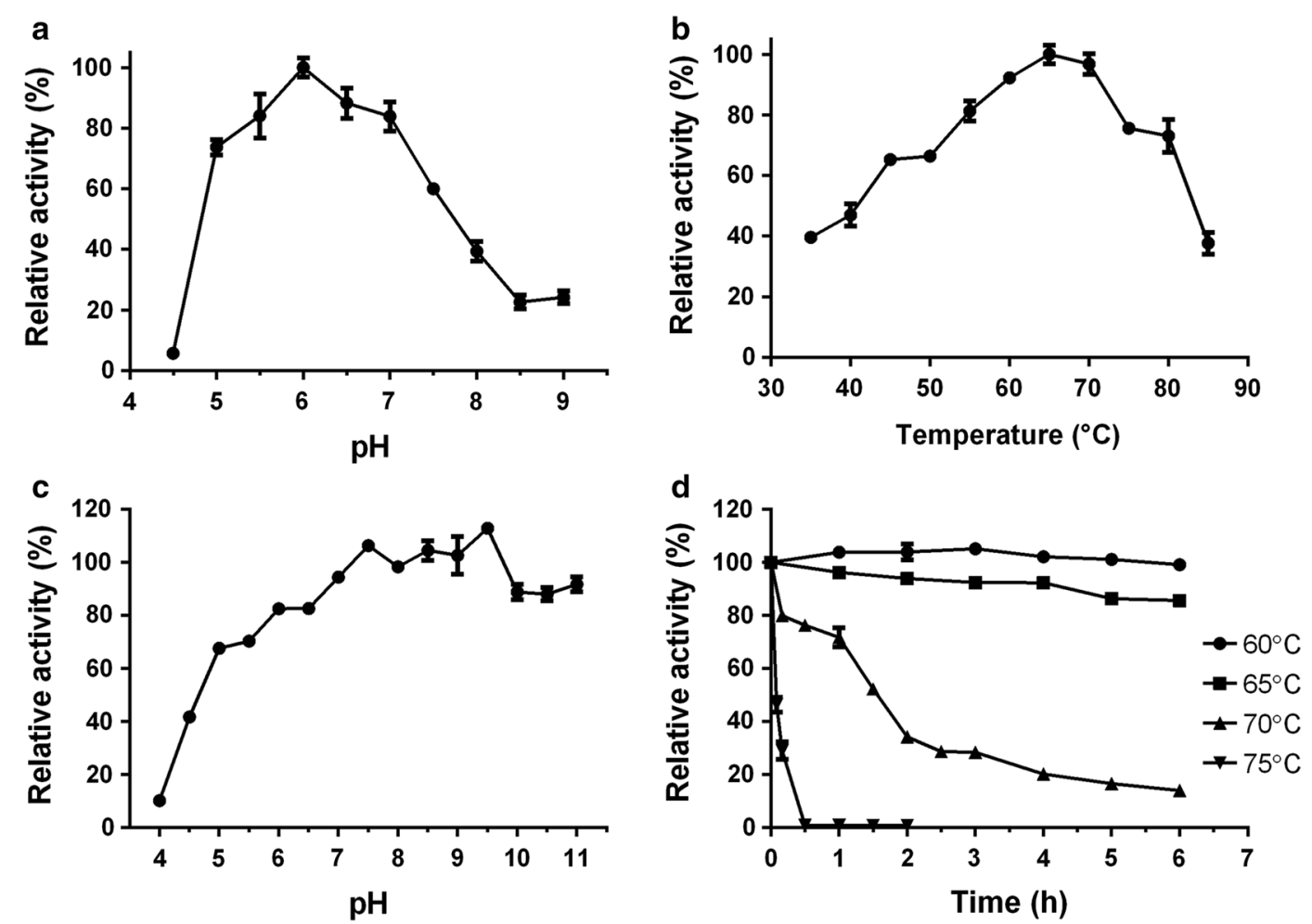

Fig. 3 Influence of $\mathrm{pH}$ and temperature on XynA. a The pH profile for xylanase activity. $\mathbf{b}$ The temperature profile for xylanase activity. $\mathbf{c}$ Influence of $\mathrm{pH}$ on the stability of XynA. $\mathbf{d}$ Thermostability analyses of XynA. Beechwood xylan was used as substrate for all assays. For optimal pH and temperature assays, the highest enzyme activity was set as 100\%. For stability assays, the activity of XynA without any treatment was set as $100 \%$. Bars denote the standard errors for three independent experiments

Table 2 Effect of various chemicals on the activity of recombinant XynA

\begin{tabular}{|c|c|c|}
\hline Chemical & $\begin{array}{l}1 \mathrm{mM} \\
\text { Relative activity (\%) }\end{array}$ & $\begin{array}{l}10 \mathrm{mM} \\
\text { Relative activity (\%) }\end{array}$ \\
\hline Control & 100 & 100 \\
\hline $\mathrm{FeCl}_{3}$ & $91.9 \pm 3.2$ & $54.5 \pm 1.2$ \\
\hline $\mathrm{FeCl}_{2}$ & $82.9 \pm 4.7$ & $52.4 \pm 1.0$ \\
\hline $\mathrm{CaCl}_{2}$ & $123.5 \pm 7.2$ & $111.3 \pm 4.8$ \\
\hline $\mathrm{MgCl}_{2}$ & $118.2 \pm 2.1$ & $143.0 \pm 4.9$ \\
\hline $\mathrm{CoCl}_{2}$ & $136.4 \pm 5.7$ & $160.0 \pm 15.5$ \\
\hline $\mathrm{AlCl}_{3}$ & $113.8 \pm 7.4$ & $9.4 \pm 3.7$ \\
\hline $\mathrm{MnCl}_{2}$ & $110.8 \pm 2.0$ & $133.2 \pm 8.4$ \\
\hline $\mathrm{ZnSO}_{4}$ & $54.0 \pm 0.9$ & $6.5 \pm 0.2$ \\
\hline $\mathrm{CuCl}_{2}$ & $35.9 \pm 5.1$ & $34.2 \pm 2.0$ \\
\hline $\mathrm{NiCl}_{2}$ & $85.2 \pm 0.9$ & $82.1 \pm 0.4$ \\
\hline EDTA & $88.6 \pm 1.9$ & $65.8 \pm 4.2$ \\
\hline Urea & $97.9 \pm 1.7$ & $87.9 \pm 3.0$ \\
\hline TritonX-100 & $104.9 \pm 5.1$ & $82.9 \pm 3.0$ \\
\hline
\end{tabular}

when increased the concentration to $10 \mathrm{mM}$. The addition of $\mathrm{Cu}^{2+}$ caused strong inhibition at both concentrations used. The enzyme activity was decreased to $54 \%$ and $6.5 \%$ during treatment with $1 \mathrm{mM}$ and $10 \mathrm{mM} \mathrm{Zn}^{2+}$, respectively. Urea and Triton X-100 had no influence on enzyme activity at the concentration of $1 \mathrm{mM}$, but slightly inhibited the enzyme activity at the concentration of $10 \mathrm{mM}$. This result indicated that high concentration of $\mathrm{Al}^{3+}, \mathrm{Zn}^{2+}$, and $\mathrm{Cu}^{2+}$ should be avoided during the application of XynA.

\section{Hydrolytic properties of XynA}

XynA was first screened for the capability to hydrolyze a group of model polysaccharides, including xylans [wheat arabinoxylan (WAX) and beechwood xylan (BeeWX)], microcrystalline cellulose substrates (filter paper and Avicel), mannans [guar gum, locust bean gum (LBG)], konjac glucomannan (KGM) (mixed linkage of glucose and mannose), galactomannan (mixed linkage of galactose and mannose), arabinans [sugar beet arabinan and debranched (DB) arabinan], galactan (galactose configured), and arabinogalactan (mixed linkage of arabinose and galactose). As shown in Fig. 4a, based on the result 

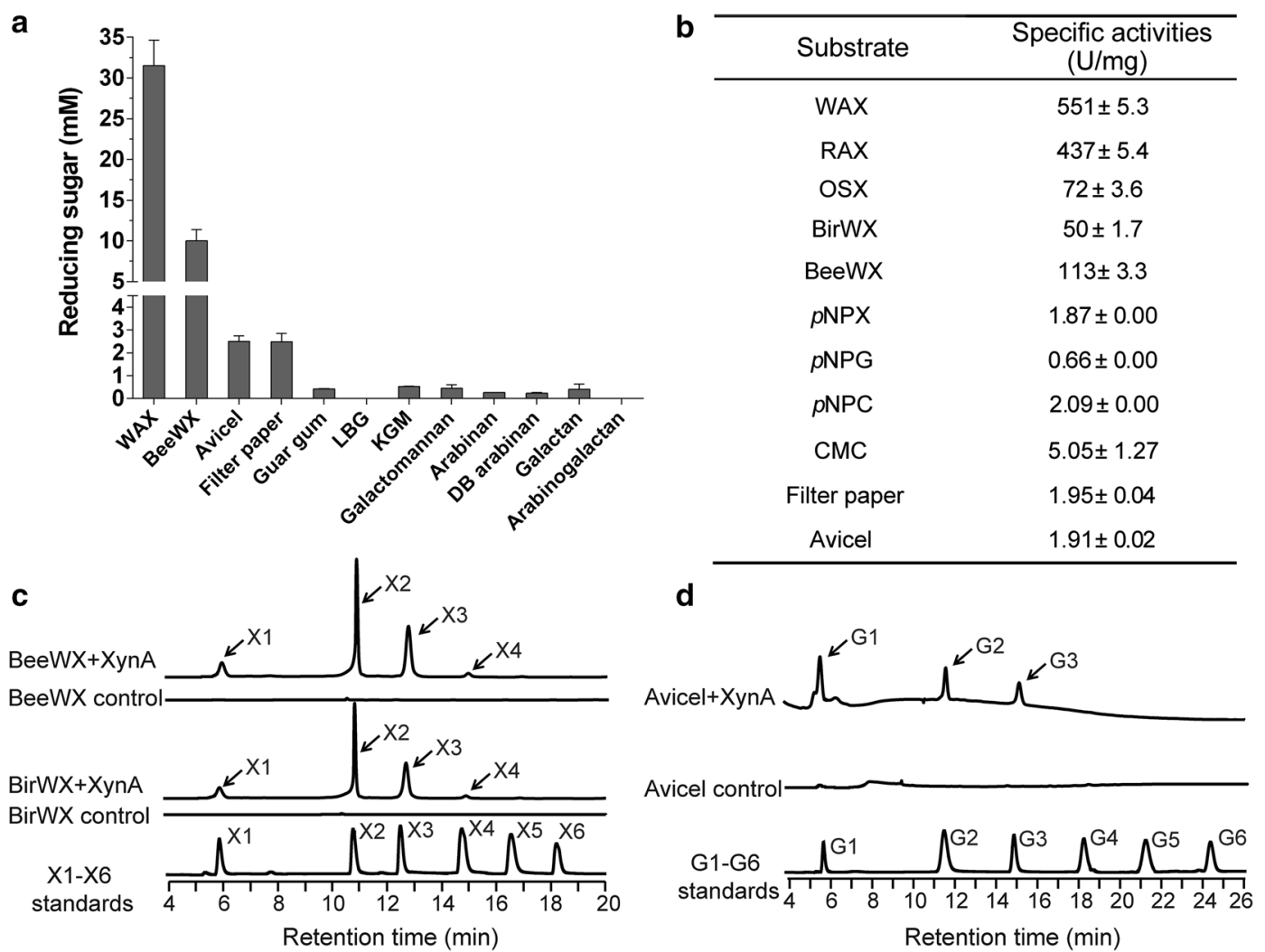

Fig. 4 Analyses of the substrate specificity of XynA. a Reducing sugar analyses of XynA on nature substrates with different glycosidic linkages. XynA $(0.5 \mu \mathrm{M})$ was incubated separately with different substrates $(5 \mathrm{mg} / \mathrm{mL})$; the reactions were performed at $\mathrm{pH} 6.0$ and $65^{\circ} \mathrm{C}$ for $30 \mathrm{~min}$. Bars denote the standard errors for three independent experiments. b Determination of the specific activities of XynA with xylans, pNP-linked sugars, and cellulose substrates. The final concentrations for all polysaccharide substrates were $10 \mathrm{mg} / \mathrm{mL}$, while the concentrations of $p N P X$, $p N P G$, and $p N P C$ were $1 \mathrm{mM}$. The reducing sugars were measured using the $p H B A H$ method, and $p N P$ was measured spectrophotometrically at $410 \mathrm{~nm}$. $\mathbf{c}$ HPAEC-PAD analyses of the hydrolytic products of hardwood xylans (birchwood xylan and beechwood xylan) by XynA. The final concentration of substrate and XynA was $10 \mathrm{mg} / \mathrm{mL}$ and $0.5 \mu \mathrm{M}$, respectively. The hydrolysis was performed at $\mathrm{pH} 6.0$ and $65^{\circ} \mathrm{C}$ for $16 \mathrm{~h}$. X $1-\mathrm{X} 6$ were mixed and analyzed to serve as standards for the assignment of the released products. $\mathbf{d}$ HPAEC-PAD analysis of the hydrolytic products of Avicel by XynA. The final concentration of substrate and XynA was $10 \mathrm{mg} / \mathrm{mL}$ and $10 \mu \mathrm{M}$, respectively. The hydrolysis was performed at pH 6.0 and $65^{\circ} \mathrm{C}$ for $16 \mathrm{~h}$. G1-G6 were mixed and analyzed to serve as standards

of the reducing sugar assays, it is easy to find that XynA was most active in xylan depolymerization; the specific activities against WAX, rye arabinoxylan (RAX), oat spelt xylan (OSX), birchwood xylan (BirWX), and BeeWX were determined to be 551, 437, 72, 50, and $113 \mathrm{U} / \mathrm{mg}$, respectively (Fig. 4b). Generally, due to the relatively simple structures, arabinoxylans are easier to degrade by xylanases than hardwood xylans and oat spelt xylan. Moreover, the enzyme exhibited activities on Avicel and filter paper as well, with a specific activity of 1.91 and $1.95 \mathrm{U} / \mathrm{mg}$ (Fig. 4a, b). Additionally, the activities toward $p$-nitrophenyl- $\beta$-D-xylopyranoside $(p \mathrm{NPX}), \quad p$ NPG, $p \mathrm{NPC}$, and CMC were determined to be 1.87, 0.66, 2.09, and $5.05 \mathrm{U} / \mathrm{mg}$ (Fig. 4b). From here, we can see that the activities of XynA on xylans were much higher than that on cellulosic substrates, indicating that xylanase activity is the main activity of the enzyme. Furthermore, XynA exhibited better performance in degrading soluble cellulose CMC than filter paper and Avicel. That is quite understandable because the structure of CMC has been decrystallized and thus generates some amorphous sites, which makes it more easily attacked by enzyme. Similar findings were observed for CbXyn10C, which showed higher activities against xylans than celluloses, and CMC was a better substrate for the enzyme than filter paper and Avicel. However, XynA could hydrolyze $p$ NPC, whereas CbXyn10C was inactive on it [13]. Reducing ends released from other substrates by XynA were insignificant.

The hydrolytic products of hardwood xylans (BirWX and BeeWX) and Avicel by XynA were further analyzed. The hydrolytic product patterns of BirWX and BeeWX were very similar; xylose (X1), xylobiose (X2), xylotriose (X3), and a little amount of xylotetraose (X4) were 
detected (Fig. 4c). Meanwhile, glucose (G1), cellobiose (G2) and cellotriose (G3) were detected in the hydrolytic product of Avicel (Fig. 4d). Analyses of the hydrolysis of oligosaccharides revealed that XynA was able to degrade xylohexaose (X6), xylopentaose (X5), xylotetraose (X4), and xylotriose (X3) into xylose (X1) and shorter oligosaccharides. However, it did not show hydrolytic activity towards xylobiose (X2), indicating that XynA is an endoxylanase (Fig. 5a). Meanwhile, XynA was able to hydrolyze all the cello-oligosaccharides. Cellotriose (G3) to cellohexaose (G6) were degraded into a set of shorter oligosaccharides, and it also exhibited weak hydrolytic activity to cellobiose (G2) (Fig. 5b).

All the results obtained indicated that XynA not only possesses xylanase activity, but also exhibits activities against CMC, microcrystalline cellulose, cellobiose, $p$ NPC, and $p$ NPG. The broad substrate spectrum makes XynA an interesting enzyme. Up to date, as shown in Table 3, only a few enzymes with a single GH10 catalytic domain were reported with bifunctional xylanase/ cellulase activities, including Cex from C. fimi [8], MFC from A. crossean [9], XynT-6 from B. stearothermophilus T-6 [10, 11], Mxyn10 from Demequina sp. JK4 [12], CbXyn10C from C. bescii DSM 6725 [13], and Xyl10A from S. olivaceoviridis E-86 [29]. Sequence similarity analysis showed that XynA showed low similarities with these enzymes, with $18 \%, 30 \%, 14 \%, 14 \%, 17 \%$, and $17 \%$ amino acid sequence identity with Cex (GenBank accession number 2HIS_A), MFC (ACC86116), XynT-6 (P40943), Mxyn10 (ACM41799), CbXyn10C (5OFL_A), and Xyl10A (WP_003978188), respectively. Xylanase activity is the main activity for these enzymes. Cex, MFC, XynT-6, Mxyn10, and Xyl10A could hydrolyze only artificial cellulose substrates such as CMC and/or $p$ NP-linked sugars. The hydrolytic properties of XynA and CbXyn10C are quite similar but with minor differences. The hydrolytic products of XynA on Avicel were G1-G3, and XynA seemed to display higher activities on $p \mathrm{NPC}$ and short cello-oligosaccharides, especially cellobiose, than CbXyn10C. However, CbXyn10C released G1-G6 during the hydrolysis of Avicel, and preferentially hydrolyzed longer cello-oligosaccharides; no activity was detected with $p \mathrm{NPC}$ as substrate. According to the structural analysis of bifunctional GH10 xylanase/cellulase [8, 29, 30], substrate-binding cleft is usually observed in the endo-acting glycoside hydrolases. The bifunctional GH10 enzymes generally exhibit much higher activities on xylans than celluloses, the underlying mechanism is supposed to be that glucose-configured substrates may be recognized and interacted with the distal regions of the binding cleft, and the interactions between binding cleft and glucoseconfigured substrates are less stable than that between the binding cleft and xylose-configured substrates. a

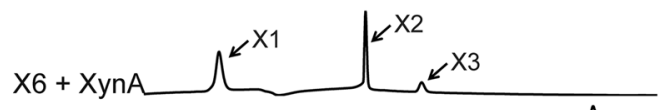

b
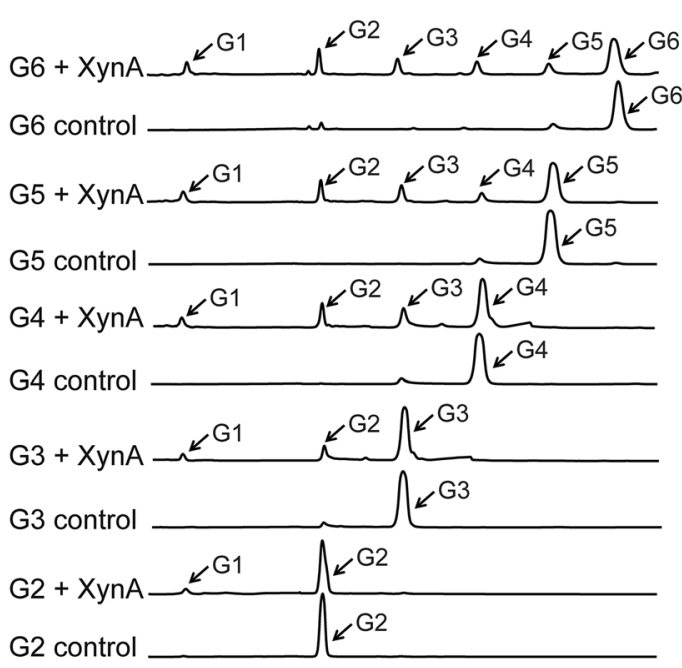

Fig. 5 Hydrolysis of xylo-oligosaccharides (X2-X6) (a) and cello-oligosaccharides (G2-G6) (b) by XynA. Each substrate (1.8 mg/mL) was incubated with purified XynA and the reaction was performed at $\mathrm{pH} 6.0,65^{\circ} \mathrm{C}$ for $12 \mathrm{~h}$; the hydrolytic products were analyzed by HPAEC-PAD 


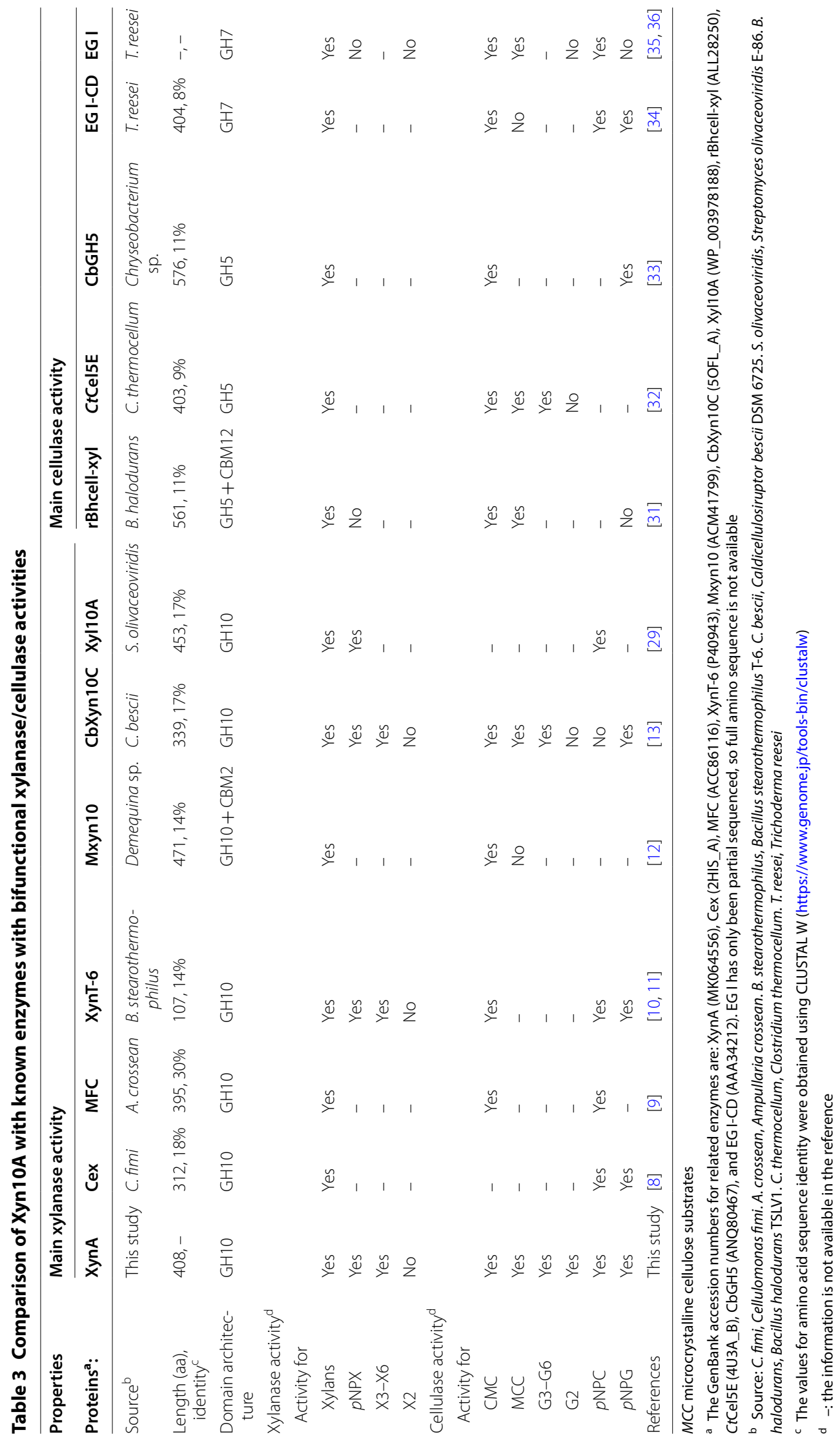


Based on the facts that XynA only released G1-G3 from Avicel during hydrolysis, we infer that during the interaction with the binding cleft of XynA, the terminals of cellulose chains from the substrate surface slide into the active site and the enzyme is likely to hydrolyze the beta-glucosidic linkages near the terminal glucosyl residue. We look forward to testing our hypothesis in future studies on the complex structures of XynA with xylo-oligosaccharide and cello-oligosaccharide ligands, and the structure-function relationship. From here, we can see that XynA is a novel enzyme evolutionarily far from already known bifunctional xylanase/cellulase belonging to GH10 family, and biochemical analyses indicated that XynA is a thermostable GH10 xylanase with extraordinary substrate promiscuity.

In the study of the structure-function relationship of CbXyn10C, the authors identified 16 key residues interplaying with both cello-oligosaccharides and xylooligosaccharides, in which 12 residues were deemed to be conserved across GH10 xylanases [30]. It is particularly worth noting that by comparing the amino acid sequence XynA with its most similar homolog rXynAHJ14, which showed 88\% identity with XynA but without activity on CMC, we found that only 15 amino acid residues are different in GH10 domains (Fig. 2). Therefore, we infer that the 15 different residues may have important influences on endowing rXynAHJ14 with cellulase activity. Based on the analyses of the nature of amino acids such as hydrophobic/hydrophilic, polar/nonpolar, and steric properties of side chains, we found that 9 out of 15 positions were of similar characteristics (Q88K, N124D, I128L, N145S, K148R, K173R, V244I, D255E, and V261I), the remaining 6 positions (D74Y, T81Q, R161N, Q196N, A254E, and A288P) may play important roles in determining the substrate preferences. This hypothesis can be tested via site-directed mutagenesis in the future.

In addition to the up-mentioned bifunctional enzymes, several enzymes with cellulase as main activity were found to exhibit xylanase activity as well; these enzymes share very low similarities with XynA [31-34]. As shown in Table 3, bifunctional enzymes from $B$. halodurans TSLV1 [31], Clostridium thermocellum [32] and Chryseobacterium sp. [33] contain a GH5 catalytic domain, while two endoglucanases from Trichoderma reesei are GH7 enzymes [34-36]. It is worth noting that many enzymes used for the comparison have not been tested with all the cellulosic substrates tested for XynA; therefore, we are uncertain of their real catalytic promiscuity. However, the hydrolytic activities XynA possesses demonstrate it has a wide substrate spectrum.

\section{Synergistic effect with cellulase in the hydrolysis} of pretreated corn stover

Corn stover is an abundant agricultural residue and used as feedstock for the production of biofuels and other bioproducts. To be more relevant with the industrial application, the cooperative action of XynA with commercial cellulase on the degradation of pretreated corn stover (PCS) was investigated. The hydrolysis of PCS by Celluclast $1.5 \mathrm{~L}$ (Novozymes) supplemented with XynA was performed at $\mathrm{pH} 6.0$ and $65{ }^{\circ} \mathrm{C}$. The time course of the PCS hydrolysis is shown in Fig. 6. The concentrations of reducing sugars produced by XynA alone were very low $(<0.4 \mathrm{mM}$ after 12 -h reaction), while the addition of XynA released significantly higher amount of reducing sugars than that produced by Celluclast $1.5 \mathrm{~L}$ alone in the whole process. Supplementing XynA with the loads of 2 and $4 \mathrm{U}_{\mathrm{BirWX}}$, after 1-h hydrolysis, the concentrations of reducing ends increased from $5.25 \mathrm{mM}$ (released by Celluclast $1.5 \mathrm{~L}$ alone) to 7.80 and $9.32 \mathrm{mM}$, increasing 48.7 and $77.6 \%$, respectively. As time went on, the increase in reducing concentrations for adding $2 / 4$ $\mathrm{U}_{\text {BirWX }} \mathrm{XynA}$ at 2, 4, 6, and $8 \mathrm{~h}$ were 36.9/74.9, 44.6/91.5, $33.8 / 92.4$, and $32.3 / 90.2 \%$, respectively. This indicates a pronounced synergistic effect of XynA with Celluclast 1.5 L on PCS hydrolysis. This phenomenon may be attributed to at least two reasons. First, the xylanase activity enabled XynA to degrade the hemicellulose fibrils intertwined with the cellulose fibrils, which facilitated cellulase to break down cellulose fibrils. Previous reports have showed that enzyme cocktails containing xylanase and cellulase are always more efficient in biomass deconstruction than cellulase monocomponent [3, 37-40]. Second, the capability of XynA to hydrolyze cellulosic substrates

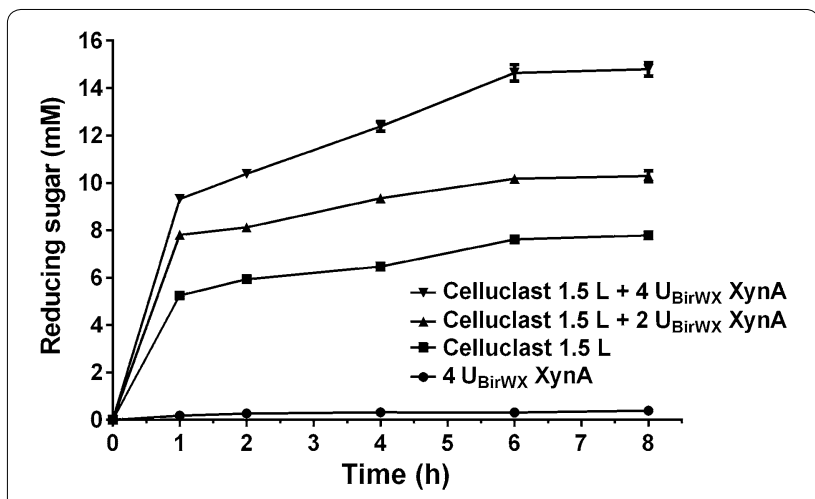

Fig. 6 Synergistic hydrolysis of pretreated corn stover by XynA and Celluclast $1.5 \mathrm{~L}$. The reaction was carried out at $\mathrm{pH} 6.0$ and $65^{\circ} \mathrm{C}$. The initial biomass was $20 \mathrm{mg} / \mathrm{mL}$; the enzyme load was $0.5 \mathrm{FPU}$ for Celluclast $1.5 \mathrm{~L}$ and 2 or $4 \mathrm{BXU}$ for XynA. Celluclast $1.5 \mathrm{~L}$ (0.5 FPU) or XynA ( $4 \cup_{\text {BirwX }}$ ) alone in the same condition was used as controls. Bars denote the standard deviations for three independent experiments 
including cello-oligosaccharides could further enhance the release of glucose monomer and short cello-oligosaccharides, and thus increases the concentration of reducing ends. Furthermore, GH10 endoxylanase was found to show better performance than its GH11 counterpart due to the influence of acetyl group in biomass and better thermostability of GH10 endoxylanase, even though GH11 endoxylanase has better activity on commercial xylan substrates [41]. Therefore, in the bioconversion of lignocellulosic biomass, efficient and thermostable GH10 xylanases with activities towards cellulosic substrates would be promising candidates to perform synergistic action with cellulase.

\section{Conclusions}

GH10 enzymes may be potential candidates with promiscuous activities. Here, a novel GH10 enzyme (XynA) was identified. Biochemical characterization revealed that XynA was very stable over a wide $\mathrm{pH}$ range and high temperatures. Particularly, XynA turned out to be able to degrade xylans and a wide variety of cellulosic substrates including $\mathrm{CMC}$, Avicel, filter paper, cellobiose, cello-oligosaccharides, $p \mathrm{NPC}$, and $p \mathrm{NPG}$, which was not reported in other GH10 enzymes. In addition, XynA showed pronounced synergistic effect with cellulase in degrading PCS. All these properties make XynA a potential candidate for assisting cellulase in the bioconversion of lignocellulosic biomass.

\section{Methods}

\section{Materials}

The Escherichia coli TOP10 and BL-21 CodonPlus(DE3) competent cells were made by following the protocols described in Molecular Cloning: A Laboratory Manual [42]. pET-28a (+) vector (Merck, Darmstadt, Germany) was used for gene expression. All molecular biology manipulations were carried out according to the manufactures' instruction. PrimeSTAR HS DNA polymerase kit, NdeI, XhoI, DNA and protein ladders were obtained from Takara (Dalian, China). T4 ligase (NEB, Ipswich, MA, USA) was used for DNA ligation. Dongsheng plasmid miniprep kit (Dongsheng Biotech, Guangzhou, China) and E.Z.N.A gel extraction kit (Omega, Guangzhou, China) were used for the extraction of plasmids and DNA fragments, respectively. The Talon metal affinity resin (Clontech, Mountain View, CA, USA) was utilized for protein purification. Locust bean gum, $p$ NPX, $p$ NPG, $p$ NPC, beechwood xylan (Lot\# X4252, $\geq 90 \%$ purity), birchwood xylan (Lot\# X0502, $\geq 90 \%$ purity), oat spelt xylan (Lot\# X0627, $\geq 70 \%$ purity), sodium carboxymethyl cellulose, and Avicel PH-101 were obtained from SigmaAldrich (St. Louis, MO, USA). Wheat arabinoxylan with medium viscosity, rye arabinoxylan with high viscosity, konjac glucomannan, galactomannan (carob), guar gum, arabinogalactan (larch wood), galactan (potato), arabinan (sugar beet), debranched arabinan (sugar beet), xylooligosaccharides (X2-X6), and cello-oligosaccharides (G2-G6) were obtained from Megazyme (Bray, Ireland). All other chemicals and reagents were of analytical grade and purchased from Guangzhou Chemical Reagent Factory (Guangzhou, Guangdong, China), unless otherwise stated.

\section{Gene cloning, expression and purification of XynA}

The genomic DNA of Bacillus sp. KW1 was used for PCR amplification of the GH10 enzyme encoding gene (xynA, GenBank accession number MK064556) via the primers xynA-F-NdeI (5'-TGCTCGGCAGCCATATGGTT AAAAAGAAAGAATTTATGAAT-3') and xynA-R-XhoI (5'-TAGTGGTGGTGCTCGAGTTATTCTACTGGTAC GATGATATCT- $3^{\prime}$ ), and the restriction enzyme sites are underlined. Purified PCR fragments and pET28a vector were treated with $N d e I$ and $X h o I$, and then ligated. Afterwards, the $E$. coli TOP10 competent cells were transformed with the ligation mixture and spread onto selective LB agar plates (50 $\mu \mathrm{g} / \mathrm{mL}$ kanamycin). Positive transformants were initially identified by colony PCR, and further verified by sequencing.

For gene expression, E. coli BL-21 CodonPlus(DE3) RIL chemical competent cells was transformed with the recombinant plasmid pET28a-xynA, then single transformant was inoculated and cultivated in $10 \mathrm{~mL}$ fresh $\mathrm{LB}$ liquid medium containing $50 \mu \mathrm{g} / \mathrm{mL}$ kanamycin (Solarbio, Beijing, China) and $25 \mu \mathrm{g} / \mathrm{mL}$ chloramphenicol (Solarbio, Beijing, China) at $37{ }^{\circ} \mathrm{C}$ with vigorous shaking $(220 \mathrm{rpm} / \mathrm{min})$ for $6 \mathrm{~h}$ on a rotary shaker (Minquan, Shanghai, China). Subsequently, the preculture was inoculated into $500 \mathrm{~mL}$ LB medium and continuously cultivated at $37^{\circ} \mathrm{C}$. When the optical density $\left(\mathrm{OD}_{600}\right)$ reached $0.6-0.8$, the culture was cooled for $10 \mathrm{~min}$ in $16^{\circ} \mathrm{C}$ water bath and then induced by adding $0.2 \mathrm{mM}$ isopropyl $\beta$-Dthiogalactopyranoside (IPTG) (Solarbio, Beijing, China). After 16-h induction, the culture was harvested by centrifugation. The collected cells were resuspended in icecold binding buffer $(50 \mathrm{mM}$ Tris- $\mathrm{HCl}, 300 \mathrm{mM} \mathrm{NaCl}$, pH7.5). To rupture cells, the suspension was passed through a D-6L high-pressure homogenizer (PhD-Tech, Saint Paul, MN, USA) thrice. The clarified supernatant containing soluble proteins was obtained by centrifuging at $4{ }^{\circ} \mathrm{C}$ with a speed of $12,000 \mathrm{~g}$ for $0.5 \mathrm{~h}$, and then subjected to heat treatment at $60{ }^{\circ} \mathrm{C}$ for $1 \mathrm{~h}$; the inactivated proteins were subsequently removed by centrifugation and the recombinant XynA was then purified using Talon cobalt resins by following the manufacturer's protocol; an elution buffer $(50 \mathrm{mM}$ Tris- $\mathrm{HCl}, 300 \mathrm{mM} \mathrm{NaCl}, 250 \mathrm{mM}$ imidazole, $\mathrm{pH}$ 7.5) was used for eluting proteins from the 
resin. The concentrations of eluted protein fractions were assayed by following the method developed by Smith et al. [43]. Samples from each eluted fraction were separated by $15 \%$ SDS-PAGE and checked after staining with Coomassie Brilliant Blue G-250. Pure protein was stored at $4{ }^{\circ} \mathrm{C}$ and used for further assay.

\section{Influence of $\mathrm{pH}$ and temperature on the xylanase activity and stability of XynA}

The $\mathrm{pH}$ optimum of XynA was determined by measuring xylanase activities in a $\mathrm{pH}$ range of $4.0-11.0$ at $50{ }^{\circ} \mathrm{C}$ for $10 \mathrm{~min}$, and beechwood xylan $(5 \mathrm{mg} / \mathrm{mL})$ was used as substrate. The following buffers were used: $\mathrm{Na}_{2} \mathrm{HPO}_{4}$-citric acid buffer (50 mM, pH 4.0-6.0), $\mathrm{Na}_{2} \mathrm{HPO}_{4}-\mathrm{NaH}_{2} \mathrm{PO}_{4}$ buffer (50 mM, pH 6.0-7.5), $50 \mathrm{mM}$ Tris-150 mM NaCl (pH 7.5-9.0) and glycine-sodium hydroxide buffer (50 mM, pH 9.0-11.0). The $p$-hydroxybenzoic acid hydrazide ( $p \mathrm{HBAH})$ method was applied to all the reducing sugar assays in this study [44]. A xylose standard curve was constructed and used for calculation of reducing ends. To determine the optimal temperature for XynA activity, assays of activity were performed at a temperature range of $35-85^{\circ} \mathrm{C}$ in $\mathrm{pH} 6.0$ buffer. For the investigation of $\mathrm{pH}$ stability, the protein was pre-incubated at $25{ }^{\circ} \mathrm{C}$ for $12 \mathrm{~h}$ in different $\mathrm{pH}$ buffers without substrate; then the residual activities were measured at $\mathrm{pH} 6.0,65{ }^{\circ} \mathrm{C}$ for $10 \mathrm{~min}$. For evaluating the thermostability, the residual activities were determined after incubated recombinant XynA individually at $60,65,70$, and $75^{\circ} \mathrm{C}$ for different periods of time; the activity of enzyme without heat treatment was used as control.

\section{Influence of different chemicals on the xylanase activity of XynA}

An array of chemicals including $\mathrm{FeCl}_{2}, \mathrm{CaCl}_{2}, \mathrm{MgCl}_{2}$, $\mathrm{MnCl}_{2}, \mathrm{ZnSO}_{4}, \mathrm{AlCl}_{3}, \mathrm{CuCl}_{2}, \mathrm{CoCl}_{2}, \mathrm{NiCl}_{2}, \mathrm{FeCl}_{3}$, urea, ethylene diamine tetraacetic acid [EDTA], and Triton $\mathrm{X}-100$ was used. Each chemical solution was individually added to the enzyme solution to a final concentration of $1 \mathrm{mM}$ or $10 \mathrm{mM}$, and the mixtures were pre-incubated at $25^{\circ} \mathrm{C}$. After 1 -h incubation, the effects were evaluated by determining the enzyme activities at $\mathrm{pH} 6.0$ and $65^{\circ} \mathrm{C}$, enzyme solution without adding any chemical was used as control. Substrate without adding enzyme solution was used as blank control.

\section{Investigation of the substrate preference of XynA}

A panel of polysaccharides including wheat arabinoxylan (WAX) ( 95\% purity, arabinose/xylose $=38 / 62)$, beechwood xylan (BeeWX), Avicel, filter paper, guar gum, locust bean gum (LBG), konjac glucomannan (KGM), galactomannan, arabinan, debranched arabinan (DB arabinan), galactan and arabinogalactan was applied to detect the substrate specificity. Each substrate $(5 \mathrm{mg} / \mathrm{mL}$, $\mathrm{pH}$ 6.0) was incubated with or without purified XynA for 30 min under the optimal $\mathrm{pH}$ and temperature, and the reducing ends released were then assayed.

To measure the specific activities towards xylans and cellulose substrates, recombinant XynA was appropriately diluted and incubated separately with natural xylans (WAX, RAX, OSX, BirWX, and BeeWX, $10 \mathrm{mg} / \mathrm{mL}$ ), $p$ NP substrates ( $p$ NPX, $p$ NPG and $p$ NPC, $1 \mathrm{mM}$ ), CMC $(10 \mathrm{mg} / \mathrm{mL})$, and microcrystalline cellulose substrates (filter paper and Avicel, $10 \mathrm{mg} / \mathrm{mL}$ ) in $50 \mathrm{mM} \mathrm{Na}_{2} \mathrm{HPO}_{4}$ $\mathrm{NaH}_{2} \mathrm{PO}_{4}$ buffer ( $\mathrm{pH} 6.0$ ) at $65^{\circ} \mathrm{C}$. The reaction time was $5 \mathrm{~min}$ for xylans and $15 \mathrm{~min}$ for other substrates. The released reducing sugars were then determined, and the produced $p N \mathrm{~N}$ was monitored spectrophotometrically at $410 \mathrm{~nm}$. One unit of enzyme activity is defined as the quantity of enzyme required to produce $1 \mu \mathrm{mol}$ of xylose equivalents/pNP/glucose equivalents in $1 \mathrm{~min}$ [31].

To analyze the hydrolytic products of hardwood xylans (BirWX and BeeWX) and Avicel by XynA, each substrate $(10 \mathrm{mg} / \mathrm{mL})$ was incubated with the enzyme in $50 \mathrm{mM}$ $\mathrm{Na}_{2} \mathrm{HPO}_{4}-\mathrm{NaH}_{2} \mathrm{PO}_{4}$ buffer ( $\mathrm{pH} 6.0$ ) at $65{ }^{\circ} \mathrm{C}$ for $16 \mathrm{~h}$; the enzyme concentration used for xylans and Avicel was 0.5 and $10 \mu \mathrm{M}$, respectively. Then, the reaction mixtures were boiled for $10 \mathrm{~min}$ and properly diluted. Analyses of hydrolytic products were performed using high-performance anion-exchange chromatography instrument equipped with CarboPac PA10 guard $(4 \times 50 \mathrm{~mm})$ and analytical $(4 \times 250 \mathrm{~mm})$ columns (Dionex, Sunnyvale, CA, USA) and a pulsed amperometric detector (HPAECPAD). Two buffers (100 mM NaOH solution and $100 \mathrm{mM}$ $\mathrm{NaOH}-500$ mM sodium acetate solution) were employed for the elution process. For the hydrolytic products of xylans, the elution was carried out by linearly increasing the concentration of sodium acetate in $100 \mathrm{mM} \mathrm{NaOH}$ from 0 to $75 \mathrm{mM}(0-20 \mathrm{~min})$, with a flow rate of $1 \mathrm{~mL} /$ min. Xylose (X1) and xylo-oligosaccharides (X2-X6) were mixed and used for the assignment of reducing sugars. For the hydrolytic products of Avicel, the elution was carried out by linearly increasing the concentration of sodium acetate in $100 \mathrm{mM} \mathrm{NaOH}$ from 0 to $112.5 \mathrm{mM}$ (0-40 min), with a flow rate of $1 \mathrm{~mL} / \mathrm{min}$. Glucose (G1) and cello-oligosaccharides (G2-G6) were mixed and used for the assignment of hydrolytic products.

\section{Evaluation of the hydrolysis of oligosaccharides}

The capacities of XynA to hydrolyze xylo-oligosaccharides (X2-X6) and cello-oligosaccharides (G2-G6) were evaluated. Each substrate $(1.8 \mathrm{mg} / \mathrm{mL})$ was incubated with purified XynA in $50 \mathrm{mM} \mathrm{Na} 2 \mathrm{HPO}_{4}-\mathrm{NaH}_{2} \mathrm{PO}_{4}$ buffer ( $\mathrm{pH}$ 6.0). The final enzyme concentration for $\mathrm{X} 2-$ $\mathrm{X} 6$ and for G2-G6 was $0.25 \mu \mathrm{M}$ and $0.5 \mu \mathrm{M}$, respectively. The reactions were carried out at $65{ }^{\circ} \mathrm{C}$. After 
12-h incubation, the enzyme was inactivated by boiling for $10 \mathrm{~min}$, and mixtures were properly diluted and analyzed by HPAEC-PAD as described above.

\section{Application of XynA in the hydrolysis of pretreated corn stover (PCS)}

Corn stover was supplied by Novozymes China, Inc (Beijing, China). PCS was prepared by following the previous report [45]. Briefly, the corn stover was smashed by an electric pulverizer (Huangdai, Jinghua, Zhejiang, China) and the fractions passed a 40-mesh sieve were collected and incubated with $15 \%$ of aqueous ammonia solution (solid:liquid=1:6). After 12-h treatment at $60^{\circ} \mathrm{C}$, the solids were collected and rinsed with deionized water until its $\mathrm{pH}$ was neutral. After being oven-dried at $80{ }^{\circ} \mathrm{C}$ for $10 \mathrm{~h}$, the solids were used for the subsequent experiments.

Synergistic hydrolysis of PCS by the commercial cellulase from Trichoderma reesei (Celluclast $1.5 \mathrm{~L}, 700$ endo-glucanase units [EGU]/g enzyme powder) (Novozymes) and $\mathrm{XynA}$ was carried out at $65{ }^{\circ} \mathrm{C}$ in $50 \mathrm{mM}$ $\mathrm{Na}_{2} \mathrm{HPO}_{4}-\mathrm{NaH}_{2} \mathrm{PO}_{4}$ buffer ( $\mathrm{pH}$ 6.0). $1 \mathrm{~mL}$ reaction mixture was made up in a 5-mL Eppendorf tube and shaken on Thermomix with a speed of $700 \mathrm{rpm} / \mathrm{min}$. The initial concentration of PCS was $20 \mathrm{mg} / \mathrm{mL}$, and the enzyme load for Celluclast $1.5 \mathrm{~L}$ and XynA was, respectively, 0.5 filter paper units (FPU) and 2 or 4 birchwood xylan units $\left(\mathrm{U}_{\mathrm{BirWX}}\right)$. Celluclast $1.5 \mathrm{~L}(0.5$ FPU) and XynA (4 $\left.U_{\text {BirWX }}\right)$ were incubated individually with $20 \mathrm{mg} / \mathrm{mL}$ PCS and the reactions were performed under the same conditions. Samples were withdrawn at regular time intervals and the enzyme was inactivated by $10 \mathrm{~min}$ incubation at $100{ }^{\circ} \mathrm{C}$. The supernatant collected after centrifugation was used for reducing sugar assay.

\section{Abbreviations \\ GH: glycoside hydrolase; CMC: carboxymethyl cellulose; $p$ NPC: $p$-nitrophenyl- $\beta$-D-cellobioside; $p N P G$ : $p N P-\beta$-D-glucopyranoside; CAZy: carbohydrate-active enzymes; GH10: GH family 10; CBM: carbohydrate-binding module; PDB: Protein Data Bank; SDS-PAGE: sodium dodecyl sulfate-polyacrylamide gel elec- trophoresis; WAX: wheat arabinoxylan; BeeWX: beechwood xylan; LBG: locust bean gum; KGM: konjac glucomannan; DB arabinan: debranched arabinan; RAX: rye arabinoxylan; OSX: oat spelt xylan; BirWX: birchwood xylan; $p N P X$ : p-nitrophenyl- $\beta$-D-xylopyranoside; $X 1$ : xylose; $X 2$ : $x y l o b i o s e ; ~ X 3$ : $x y l o t r i o s e ; ~ X 4$ : xylotetraose; X5: xylopentaose; X6: xylohexaose; G1: glucose; G2: cellobiose; G3: cellotriose; G4: cellotetraose; G5: cellopentaose; G6: cellohexaose; IPTG: iso- propyl $\beta$-D-thiogalactopyranoside; $p$ HBAH: $p$-hydroxybenzoic acid hydrazide.}

\section{Authors' contributions}

KW and SW obtained the funding, designed the study, supervised the experiments and wrote the manuscript. KW and RC performed the major experiments containing gene cloning, enzyme production and substrate specificity assay. KW, RC, MW and QL performed the HPAEC analysis and the hydrolysis of the pretreated corn stover. RZ and HX participated in the discussion and helped to revise the manuscript. All authors read and approved the final manuscript.

\section{Author details \\ ${ }^{1}$ Research Center of Chinese Herbal Resource Science and Engineering, Guangzhou University of Chinese Medicine, Guangzhou Higher Education Mega Center, No.232 Outer Ring West Rd., Panyu District, Guangzhou 510006, Guangdong, China. ${ }^{2}$ Key Laboratory of Chinese Medicinal Resource from Lingnan, Ministry of Education, Guangzhou University of Chinese Medicine, Guangzhou Higher Education Mega Center, No.232 Outer Ring West Rd., Panyu District, Guangzhou 510006, Guangdong, China. ${ }^{3}$ Joint Laboratory of National Engineering Research Center for the Pharmaceutics of Traditional Chinese Medicines, Guangzhou University of Chinese Medicine, Guangzhou Higher Education Mega Center, No.232 Outer Ring West Rd., Panyu District, Guangzhou 510006, Guangdong, China. ${ }^{4}$ College of Fundamental Medical Science, Guangzhou University of Chinese Medicine, Guangzhou Higher Education Mega Center, No.232 Outer Ring West Rd., Panyu District, Guang- zhou 510006, Guangdong, China.}

\section{Acknowledgements}

Not applicable.

\section{Competing interests}

The authors declare that they have no competing interests.

\section{Availability of data and materials}

The datasets used and/or analyzed during the current study are available from the corresponding author upon reasonable request.

\section{Consent for publication}

All authors consent for publication.

\section{Ethics approval and consent to participate} Not applicable.

\section{Funding}

This work was supported by the following grants: National Natural Science Foundation of China (31802099), Natural Science of Foundation of Guangdong Province, China (2018A030310497), Research Program for Young Innovative Talents in Higher Education Institutions of Guangdong Province (2017KQNCX037), and the start-up fundings of Guangzhou University of Chinese Medicine (A1-AFD018161Z0105 \& A1-AFD018171Z11016).

\section{Publisher's Note}

Springer Nature remains neutral with regard to jurisdictional claims in published maps and institutional affiliations.

Received: 14 January 2019 Accepted: 25 February 2019

Published online: 09 March 2019

\section{References}

1. Takkellapati S, Li T, Gonzalez MA. An overview of biorefinery derived platform chemicals from a cellulose and hemicellulose biorefinery. Clean Technol Environ Policy. 2018;20:1615-30.

2. Pauly M, Keegstra K. Cell-wall carbohydrates and their modification as a resource for biofuels. Plant J. 2008;54:559-68.

3. Long L, Tian D, Zhai R, Li X, Zhang Y, Hu J, et al. Thermostable xylanaseaided two-stage hydrolysis approach enhances sugar release of pretreated lignocellulosic biomass. Bioresour Technol. 2018;257:334-8.

4. Broeker J, Mechelke M, Baudrexl M, Mennerich D, Hornburg D, Mann M, et al. The hemicellulose-degrading enzyme system of the thermophilic bacterium Clostridium stercorarium: comparative characterisation and addition of new hemicellulolytic glycoside hydrolases. Biotechnol Biofuels. 2018;11:229.

5. Guo ZP, Duquesne S, Bozonnet S, Nicaud JM, Marty A, O'Donohue MJ. Expressing accessory proteins in cellulolytic Yarrowia lipolytica to improve the conversion yield of recalcitrant cellulose. Biotechnol Biofuels. 2017;10:298 
6. Bhalla A, Bansal N, Kumar S, Bischoff KM, Sani RK. Improved lignocellulose conversion to biofuels with thermophilic bacteria and thermostable enzymes. Bioresour Technol. 2013;128:751-9.

7. Lombard V, Golaconda Ramulu H, Drula E, Coutinho PM, Henrissat B. The carbohydrate-active enzymes database (CAZy) in 2013. Nucleic Acids Res. 2014;42:D490-5.

8. Notenboom V, Birsan C, Warren RAJ, Withers SG, Rose DR. Exploring the cellulose/xylan specificity of the beta-1,4-glycanase Cex from Cellulomonas fimi through crystallography and mutation. Biochemistry. 1998;37:4751-8

9. Cheng S, Yang P, Guo L, Lin J, Lou N. Expression of multi-functional cellulase gene $\mathrm{mfc}$ in Coprinus cinereus under control of different basidiomycete promoters. Bioresour Technol. 2009:100:4475-80.

10. Gat O, Lapidot A, Alchanati I, Regueros C, Shoham Y. Cloning and DNA sequence of the gene coding for Bacillus stearothermophilus T-6 xylanase. Appl Environ Microbiol. 1994;60:1889-96.

11. Khasin A, Alchanati I, Shoham Y. Purification and characterization of a thermostable xylanase from Bacillus stearothermophilus T-6. Appl Environ Microbiol. 1993;59:1725-30.

12. Meng $X$, Shao Z, Hong Y, Lin L, Li C, Liu Z. A novel pH-stable, bifunctional xylanase isolated from a deep-sea microorganism, Demequina sp. JK4. J Microbiol Biotechnol. 2009;19:1077-84.

13. Xue XL, Wang R, Tu T, Shi PJ, Ma R, Luo HY, Yao B, Su XY. The N-terminal GH10 domain of a multimodular protein from Caldicellulosiruptor bescii is a versatile xylanase/beta-glucanase that can degrade crystalline cellulose. Appl Environ Microbiol. 2015;81:3823-33.

14. Zhou J, Wu Q, Zhang R, Mo M, Tang X, Li J, et al. A thermo-halo-tolerant and proteinase-resistant endoxylanase from Bacillus sp. HJ14. Folia Microbiol. 2014;59:423-31.

15. Bai W, Xue Y, Zhou C, Ma Y. Cloning, expression and characterization of a novel salt-tolerant xylanase from Bacillus sp. SN5. Biotechnol Lett. 2012;34:2093-9.

16. Zhou J, Dong Y, Tang X, Li J, Xu B, Wu Q, et al. Molecular and biochemical characterization of a novel intracellular low-temperature-active xylanase. J Microbiol Biotechnol. 2012;22:501-9.

17. Kumar V, Satyanarayana T. Biochemical and thermodynamic characteristics of thermo-alkali-stable xylanase from a novel polyextremophilic Bacillus halodurans TSEV1. Extremophiles. 2013;17:797-808.

18. Nakamura S, Nakai R, Wakabayashi K, Ishiguro Y, Aono R, Horikoshi K. Thermophilic alkaline cylanase from newly isolated alkaliphilic and thermophilic Bacillus sp. Strain TAR-1. Biosci Biotechnol Biochem. 1994;58:78-81.

19. Nakatani K, Katano Y, Kojima K, Takita T, Yatsunami R, Nakamura S, et al. Increase in the thermostability of Bacillus sp. strain TAR-1 xylanase using a site saturation mutagenesis library. Biosci Biotechnol Biochem. 2018;82:1715-23.

20. Bhardwaj A, Leelavathi S, Mazumdar-Leighton S, Ghosh A, Ramakumar S, Reddy VS. The critical role of partially exposed $\mathrm{N}$-terminal valine residue in stabilizing GH10 xylanase from Bacillus sp. NG-27 under poly-extreme conditions. PLoS ONE. 2008;3:e3063.

21. Chang P, Tsai WS, Tsai CL, Tseng MJ. Cloning and characterization of two thermostable xylanases from an alkaliphilic Bacillus firmus. Biochem Biophys Res Commun. 2004;319:1017-25.

22. Mamo G, Hatti-Kaul R, Mattiasson B. A thermostable alkaline active endo-beta-1-4-xylanase from Bacillus halodurans S7: purification and characterization. Enzyme Microb Technol. 2006;39:1492-8.

23. Zhang G, Mao L, Zhao Y, Xue Y, Ma Y. Characterization of a thermostable xylanase from an alkaliphilic Bacillus sp. Biotechnol Lett. 2010;32:1915-20.

24. Bhalla A, Bischoff KM, Uppugundla N, Balan V, Sani RK. Novel thermostable endo-xylanase cloned and expressed from bacterium Geobacillus sp. WSUCF1. Bioresour Technol. 2014:165:314-8.

25. Su XY, Han YJ, Dodd D, Moon YH, Yoshida S, Mackie RI, Cann IKO. Reconstitution of a thermostable xylan-degrading enzyme mixture from the bacterium Caldicellulosiruptor bescii. Appl Environ Microbiol. 2013;79:1481-90.

26. You S, Chen CC, Tu T, Wang X, Ma R, Cai HY, et al. Insight into the functional roles of Glu175 in the hyperthermostable xylanase XYL10C-DeltaN through structural analysis and site-saturation mutagenesis. Biotechnol Biofuels. 2018;11:159.
27. Wang K, Pereira GV, Cavalcante JJV, Zhang ML, Mackie R, Cann I. Bacteroides intestinalis DSM 17393, a member of the human colonic microbiome, upregulates multiple endoxylanases during growth on xylan. Sci Rep. 2016;6:34360.

28. Derewenda U, Swenson L, Green R, Wei YY, Morosoli R, Shareck F, et al. Crystal-structure, at 2.6-angstrom resolution, of the Streptomyces lividans xylanase-A, a member of the F-family of beta-1,4-D-glycanases. J Biol Chem. 1994;269:20811-4.

29. Ichinose H, Diertavitian S, Fujimoto Z, Kuno A, Lo Leggio L, Kaneko S. Structure-based engineering of glucose specificity in a family 10 xylanase from Streptomyces olivaceoviridis E-86. Process Biochem. 2012;47:358-65.

30. Chu YD, Tu T, Penttinen L, Xue XL, Wang XY, Yi ZL, et al. Insights into the roles of non-catalytic residues in the active site of a $\mathrm{GH} 10$ xylanase with activity on cellulose. J Biol Chem. 2017:292:19315-27.

31. Rattu G, Joshi S, Satyanarayana T. Bifunctional recombinant cellulasexylanase (rBhcell-xyl) from the polyextremophilic bacterium Bacillus halodurans TSLV1 and its utility in valorization of renewable agro-residues. Extremophiles. 2016;20:831-42.

32. Yuan SF, Wu TH, Lee HL, Hsieh HY, Lin WL, Yang B, et al. Biochemical characterization and structural analysis of a bifunctional cellulase/xylanase from Clostridium thermocellum. J Biol Chem. 2015;290:5739-48.

33. Tan H, Miao R, Liu T, Yang L, Yang Y, Chen C, et al. A bifunctional cellulasexylanase of a new Chryseobacterium strain isolated from the dung of a straw-fed cattle. Microb Biotechnol. 2018:11:381-98.

34. Nakazawa H, Okada K, Kobayashi R, Kubota T, Onodera T, Ochiai N, et al. Characterization of the catalytic domains of Trichoderma reesei endoglucanase I, II, and III, expressed in Escherichia coli. Appl Microbiol Biotechnol. 2008:81:681-9.

35. Gao D, Chundawat SP, Krishnan C, Balan V, Dale BE. Mixture optimization of six core glycosyl hydrolases for maximizing saccharification of ammonia fiber expansion (AFEX) pretreated corn stover. Bioresour Technol. 2010;101:2770-81.

36. Gao D, Chundawat S, Liu T, Hermanson S, Gowda K, Brumm P, et al. Strategy for identification of novel fungal and bacterial glycosyl hydrolase hybrid mixtures that can efficiently saccharify pretreated lignocellulosic biomass. BioEnergy Res. 2010;3:67-81.

37. Shibata N, Suetsugu M, Kakeshita H, Igarashi K, Hagihara H, Takimura Y. A novel GH10 xylanase from Penicillium sp. accelerates saccharification of alkaline-pretreated bagasse by an enzyme from recombinant Trichoderma reesei expressing Aspergillus beta-glucosidase. Biotechnol Biofuels. 2017;10:278.

38. Song HT, Gao Y, Yang YM, Xiao WJ, Liu SH, Xia WC, et al. Synergistic effect of cellulase and xylanase during hydrolysis of natural lignocellulosic substrates. Bioresour Technol. 2016;219:710-5.

39. Peng X, Qiao W, Mi S, Jia X, Su H, Han Y. Characterization of hemicellulase and cellulase from the extremely thermophilic bacterium Caldicellulosiruptor owensensis and their potential application for bioconversion of lignocellulosic biomass without pretreatment. Biotechnol Biofuels. 2015:8:131.

40. Pennacchio A, Ventorino V, Cimini D, Pepe O, Schiraldi C, Inverso M, et al. Isolation of new cellulase and xylanase producing strains and application to lignocellulosic biomasses hydrolysis and succinic acid production. Bioresour Technol. 2018:259:325-33.

41. Hu JG, Saddler JN. Why does GH10 xylanase have better performance than $\mathrm{GH} 11$ xylanase for the deconstruction of pretreated biomass? Biomass Bioenergy. 2018;110:13-6.

42. Green MR, Sambrook J. Molecular cloning: a laboratory manual. New York: Cold Spring Harbor Laboratory Press; 2012

43. Smith PK, Krohn RI, Hermanson GT, Mallia AK, Gartner FH, Provenzano $\mathrm{MD}$, et al. Measurement of protein using bicinchoninic acid. Anal Biochem. 1985;150:76-85.

44. Lever M. A new reaction for colorimetric determination of carbohydrates. Anal Biochem. 1972;47:273-9.

45. Kim TH, Lee YY. Pretreatment of corn stover by soaking in aqueous ammonia at moderate temperatures. Appl Biochem Biotech. 2007:137:81-92. 